\title{
MOLECULAR STRUCTURE AND HYBRIDIZATION PATTERNS OF Abramis brama $\times$ Ruti- Ius rutilus HYBRIDS FROM MODRAC RESERVOIR, BOSNIA AND HERZEGOVINA
}

\author{
Belma Kalamujić Stroil ${ }^{1 *}$, Lejla Ušanovići ${ }^{1}$, Abdurahim Kalajdžić ${ }^{1}$, Lejla Lasić ${ }^{1}$, Rifat Škrijelj ${ }^{2}$, Naris Pojskić ${ }^{1}$ \\ ${ }^{1}$ University of Sarajevo-Institute for Genetic Engineering and Biotechnology, Zmaja od Bosne 8, Sarajevo, \\ Bosnia and Herzegovina \\ ${ }^{2}$ University of Sarajevo-Faculty of Science, Zmaja od Bosne 33-35, Sarajevo, Bosnia and Herzegovina
}

*Corresponding Author: belma.kalamujic@ingeb.unsa.ba

\section{ARTICLE INFO}

Received: 6 May 2021

Accepted: 12 July 2021

\section{ABSTRACT}

Interspecific hybridization in the Cyprinidae family has been recorded worldwide, with Abramis brama (bream) and Rutilus rutilus (roach) as one of the often-reported hybridizing pairs. The only account of such an event in Bosnia and Herzegovina has been in Modrac Reservoir. Using morphological and molecular markers, the presence of hybrids was surveyed, the hybridization direction was determined and the hybrid group structure in this ecosystem was evaluated. Our findings confirmed unhindered natural hybridization between roach and bream in Modrac Reservoir. Over $50 \%$ of the hybrid specimens were classified as $F_{2}$ hybrids by the NewHybrids software, while the rest were categorized as pure parental form, making it the first such finding in Europe. The analysis of mitochondrial cytochrome $b$ showed that $90 \%$ of hybrid individuals were of bream maternal origin. The hybrid group expressed higher mean values of observed heterozygosity and gene diversity than both parental species. Signs of introgressive hybridization between parental species were detected. The hybrid zone of Modrac Reservoir appears to follow the intermediate or "flat" hybrid model based on the balanced distribution of parental and hybrid genotypes. Further investigation is needed to elucidate the factors that enable the survival and mating success of post- $F_{1}$ individuals.

Kalamujić Stroil, B., Ušanović, L., Kalajdžić, A., Lasić, L., Škrijelj, R., Pojskić, N. (2021): Molecular structure and hybridization patterns of Abramis brama $\times$ Rutilus rutilus hybrids from Modrac Reservoir, Bosnia and Herzegovina. Croatian Journal of Fisheries, 79, 147-156. DOI: 10.2478/cjf-2021-0016. 


\section{INTRODUCTION}

An increase in hybridization rates, both interspecific and intraspecific, has become a major issue in conservation biology worldwide due to anthropogenically-influenced habitat modifications and species translocation (Frankham et al., 2002). Hybridization is more common in fish than in any other vertebrate group (Allendorf and Waples, 1996). Several factors drive the hybridization process between closely related fish taxa: a) loss or degradation of natural habitat, b) competition for common or limited habitat, feeding or spawning grounds, c) parental species occurring in unequal abundances, d) external mechanisms of fertilization, e) introduction of allochthonous species, $f$ ) weak isolating mechanisms, g) aquaculture and fisheries (Campton, 1987; reviewed in Scribner et al., 2001). Hybridization can result in progeny so poorly adapted to local conditions they do not reach maturity or that are fertile and able to backcross with parental species, leading to gene introgression (Leary et al., 1995).

Scribner et al. (2001) summarized the data from 158 articles reporting on the hybridization between freshwater fish species, mostly in North American rivers. Out of 168 species and 139 species pairs from 19 families, the most frequent hybridization was detected within the family Cyprinidae, accounting for $40 \%$ of all hybrids represented. One of the best-studied hybridization cases in this family is between bream Abramis brama (L. 1758) and roach Rutilus rutilus (L. 1758). This cross has been welldocumented across Europe and the British Isles (Cowx, 1983; Wyatt et al., 2006; Kuparinen et al., 2014), being especially frequent in Ireland where these hybrids often exceed the abundance of both parental species (Hayden et al., 2010; Toscano et al., 2010). Temporal overlap of spawning activities and similar spawning habitats facilitate hybridization between these two parental species (Pitts et al., 1997). Under laboratory conditions, Wood and Jordan (1987) found that hybrids between roach and bream are fertile, showing $F_{1}$-hybrid $\times$ roach (female named first), roach $\times F_{1}$-hybrid and $F_{1}$-hybrid $\times F_{1}^{-}$ hybrid as hybrids or backcrosses that produced fry, and bream $\times$ roach cross as a hybrid that failed to produce fertile eggs. However, the crossing of bream and roach (female first) was successful under controlled conditions in a study by Matondo et al. (2008). Though the possibility of backcross of $F_{1}$-hybrids with either parental species has been demonstrated under controlled conditions (Pitts et al., 1997), the frequency of occurrence of $F_{2}$-hybrids in nature is low (Wyatt et al., 2006; Hayden et al., 2010; Kuparinen et al., 2014, Konopiński and Amirowicz, 2017). The variation in observable morphometric and meristic characteristics in the hybrid offspring is likely increased by backcrossing, aggravating the identification problems (Wood and Jordan, 1987).

Given the limitations of the morphological approach in detecting post- $\mathrm{F}_{1}$ hybrids, hybridization and introgression are best investigated using heritable genetic markers. Since hybrids carry nuclear DNA makeup from both parents, $F_{1}$ individuals can be detected based on a single locus displaying different alleles in parental species. However, to confidently identify post- $F_{1}$ and backcrossed individuals, at least three to five loci should be screened (Pacheco et al., 2002), to account for the effects of segregation during meiosis. The usual type of nuclear markers employed in the hybridization studies on cyprinids are microsatellites (Hamilton and Tyler, 2008; Dubut et al., 2010) and internal transcribed spacer 1 (ITS1) region of nuclear ribosomal DNA (nrDNA) (Wyatt et al., 2006; Hayden et al., 2010). Matrilineally inherited mitochondrial (mtDNA) cytochrome $b(c y t b)$ gene is commonly used to test the direction of hybridization (Wyatt et al., 2006; Perea et al., 2010).

In Bosnia and Herzegovina, bream and roach overlap in their distributions, both species being common in the lowland rivers of the Black Sea basin (Sofradžija, 2009). The only report of $R$. rutilus $\times A$. brama hybrids in Bosnia and Herzegovina was given by Adrović et al. (2009a). In that study, 65 specimens of bream, 41 of roach and 54 of hybrid individuals were caught in Modrac Reservoir (the Sava river drainage) near Tuzla. Out of 22 biometric characters, two morphological traits most prominently discriminated hybrids from parental species: the length of the anal fin base and the number of rays in the anal fin. Compared to bream, hybrid individuals displayed a shorter anal fin base and fewer rays in the anal fin but had longer anal fin with more rays than in roach. The authors concluded that molecular genetic studies should be conducted to confirm the results of morphological analysis.

This study aimed to test the discrimination power of morphological traits in detecting roach $\times$ bream hybrids from Modrac Reservoir (northern Bosnia and Herzegovina) in comparison to the nuclear ITS1 region and seven microsatellite markers. Also, mitochondrial cytochrome $b$ was analyzed to determine the maternal origin of hybrid individuals. Finally, the sample was assessed for the presence of post- $F_{1}$ individuals using NewHybrids software.

\section{MATERIALS AND METHODS}

\section{Sampling}

In total, 161 fish were caught from Modrac Reservoir in 2009 using the sets of three gillnets (mesh sizes 10, 30 and $50 \mathrm{~mm}$ ). Fish were initially identified as bream, roach or hybrid, according to the Vuković and Ivanović (1971) determination key. Hybrid individuals were further confirmed based on morphological observations of the length of the anal fin base and the number of rays in the anal fin, following Adrović et al. (2009a). Clippings of abdominal fins were taken and stored in individual tubes with $96 \%$ ethanol until further analysis. 


\section{DNA isolation}

DNA was extracted from abdominal fins following the salting-out protocol (Miller et al., 1988) and optimized for DNA isolation from fin tissue by Durmić-Pašić et al. (2005). The quality and yield of genomic DNA were tested by horizontal gel electrophoresis in SB buffer (Brody and Kern, 2005).

Analysis of ITS region, the mitochondrial cytochrome $b$ and microsatellite markers

Primer sequences and protocols for the amplification of ITS1 (product size of $385 \mathrm{bp}$ and $152 \mathrm{bp}$ for bream and roach, respectively) and cytochrome $b$ (product size of 672 $\mathrm{bp}$ and $450 \mathrm{bp}$ for bream and roach, respectively) regions were as in Wyatt et al. (2006). Analyses of PCR products were done on $1.5 \%$ agarose gel stained with ethidium bromide. Based on previous reports of successful crossamplification in different cyprinid species (Hamilton and Tyler, 2008), seven microsatellite loci - Ca1, Ca3 (Dimsoski et al., 2000), CypG24, CypG27, CypG30 (Baerwald and May, 2004), Rru2 (Barinova et al., 2004) and Z21908 (http://zfin.org/) - were selected. All loci were amplified in $15 \mu \mathrm{l}$ multiplex PCRs containing $1 \times$ PCR buffer, $3 \mathrm{mM}$ $\mathrm{MgCl}_{2}, 0.5 \mathrm{mM}$ dNTPs, $1 \mathrm{U}$ Taq polymerase, $50 \mathrm{ng}$ of DNA, and primers in final concentrations of $0.05 \mu \mathrm{M}$ for CypG24, $0.1 \mu \mathrm{M}$ for Ca1, Rru2 and Z21908, 0.2 $\mu \mathrm{M}$ for CypG30, and $0.5 \mu \mathrm{M}$ for $\mathrm{Ca} 3$ and CypG27. Touchdown reaction was employed, consisting of 2 min of initial denaturation at $95^{\circ} \mathrm{C}$, followed by $30 \mathrm{sec}$ at $95^{\circ} \mathrm{C}, 30 \mathrm{sec}$ at the annealing temperature and $45 \mathrm{sec}$ elongation at $72^{\circ} \mathrm{C}$, with $10 \mathrm{~min}$ of final extension at $72^{\circ} \mathrm{C}$. The annealing temperature was decreased every five cycles $\left(62^{\circ} \mathrm{C}, 58^{\circ} \mathrm{C}, 55^{\circ} \mathrm{C}, 53^{\circ} \mathrm{C}, 51^{\circ} \mathrm{C}\right.$, $49^{\circ} \mathrm{C}, 47^{\circ} \mathrm{C}$ ), as suggested in Hamilton and Tyler (2008). Allele sizing was performed using GeneMapper ID v3.2 software on ABI PRISM ${ }^{\mathrm{TM}} 310$ Genetic Analyzer.

\section{Biostatistical data analysis and population-genetic analysis}

To estimate the difference in the percentage of detected roach, bream and hybrid individuals based on morphological traits and molecular ITS1 marker, the concordance correlation coefficient (Lin, 1989; Lin, 2000) was used within MedCalc for Windows, version 19.4 (MedCalc Software, Ostend, Belgium). GenAlEx 6.5 (Peakall and Smouse, 2012) was used to calculate genetic indices in order to estimate the diversity of three analyzed groups (bream, roach and hybrids). These indices included a number of detected and effective alleles, allele frequencies based on the direct counting, observed (Hartl and Clark, 1997; Meirmans and Hedrick, 2011) and expected (Nei, 1987) heterozygosity and intrapopulation inbreeding (fixation index) (Hartl and Clark, 1997). A simple ratio between the number of effective and detected alleles $\left(A_{E} / A_{N}\right)$ was used as suggested by Pojskić and Kalamujic
(2015). This measure indicates a possible degree of deviation between the effective number of alleles and the number detected by direct counting. Ratio and its $P$ values were implemented within the ALRATIO R script (Pojskić, 2019). A Z-score of $P<0.01$ was considered statistically significant. Deviation from Hardy-Weinberg equilibrium was tested by calculating $\chi^{2}$ (Hedrick, 1999) with the significance level set to $P<0.05$. Wright's F statistics (Hartl and Clark, 1997; Meirmans and Hedrick, 2011), pairwise Fst and AMOVA (Excoffier et al., 1992) were estimated in order to measure the genetic differentiation among analyzed groups. The population assignment test (Paetkau et al., 1995; Paetkau et al., 2004) was conducted using GENECLASS2 software (Piry et al., 2004) to investigate the relationship between the hybrids and parental species. Principal Coordinates Analysis (PCOA) was performed on the basis of the results of genetic distance between analyzed groups using GenAIEx 6.5 (Peakall and Smouse, 2012). Estimation of the $K$ value $(\Delta K)$ was performed using STRUCTURE HARVESTER software (Dent and von Holdt, 2012). A STRUCTURE test (Pritchard et al., 2000) was performed applying Markov chain Monte-Carlo (MCMC) analysis (admixture model, $\mathrm{K}=2$, burn-in period 100,000 and 200,000 iterations) to estimate possible hybridization. Assignment of individuals to clusters was provided by a probability of membership ql set at $90 \%$ for parental species and $0.1<q \mid<0.9$ for hybrids (Vähä and Primmer, 2006). NewHybrids (Anderson and Thompson, 2002) was used to classify hybrid individuals into different categories $\left(F_{1}, F_{2}\right.$ and backcross). The threshold qi values of belonging to a certain hybrid class were set up to qi> 0.5 , following Aboim et al. (2010). To avoid overfitting, the following parameters were used: 100,000 MCMC sweeps after an initial burn-in period of 50,000 sweeps.

\section{RESULTS}

Based on morphological screening, 161 individuals were classified as 62 roach, 55 bream and 44 hybrids. Amplification of the ITS1 region was successful for 152 samples, giving the expected band sizes for roach and bream, $152 \mathrm{bp}$ and $385 \mathrm{bp}$, respectively, while hybrid individuals displayed both bands. Analysis of the ITS1 region revealed that out of 40 samples that produced two bands, $87.5 \%$ of them were previously morphologically identified as hybrid individuals, while $2.5 \%$ and $10 \%$ were classified as roach and bream, respectively. Further, nine individuals, identified as hybrids based on morphological criteria, produced the ITS1 band characteristic of roach. There was a substantial concordance in the percentage of detected roach, bream and hybrid individuals based on morphological traits and molecular ITS1 marker (Pearson $P=0.961$ ) (Fig. 1). 


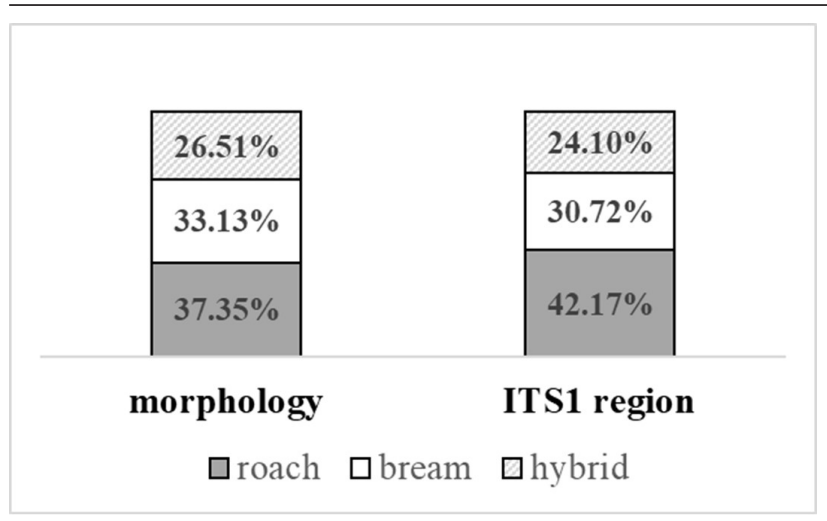

Fig 1. Agreement of detected species and hybrids based on morphological and molecular markers (ITS1 region)

To determine the maternal origin of hybrid individuals, the mitochondrial cytochrome $b$ was amplified using allele-specific amplification. Four of the roach $\times$ bream hybrids (10\%) were found to have roach maternal origin, while 36 specimens (90\%) were of bream maternal origin. Of seven investigated microsatellite loci, five were polymorphic in both bream and roach, as well as in hybrids (Table 1). Locus Rru2 displayed only one allele (92 bp) in bream, while locus CypG30 failed to give reproducible amplification in roach from Modrac Reservoir. Therefore, loci Rru2 and CypG30 were excluded from further analysis. Private alleles were observed for all five loci used in genetic indices calculations (Table 1).

Locus Rru2 produced the smallest number of detected alleles $\left(A_{N}\right)$ in all three investigated groups $(9,1$ and 5 alleles in roach, bream and hybrids, respectively) while locus $\mathrm{Ca} 3$ was most polymorphic across the sample. However, the number of effective alleles $\left(A_{E}\right)$ was significantly lower than detected alleles $\left(A_{N}\right)$, with $P$ value lower than 0.01 for CypG24 in the bream group. Observed heterozygosity and gene diversity were high (mean 0.749 and 0.858 , respectively) in roach, while both indices varied across loci in bream and had reduced mean values (0.592 and 0.731 , respectively).
The mean values of heterozygosity (0.759) and gene diversity (0.884) were quite high in hybrid individuals. The level of inbreeding (F) varied among loci, with mean values of $0.123,0.247$ and 0.147 in roach, bream and hybrids, respectively (Table 2 ).

Table 2. Mean values over loci for each group. $N$ - number of individuals, $A_{N}$ - number of detected alleles, $A_{E}$ - number of effective alleles, $H_{o}$ - observed heterozygosity, $H_{e}$ - gene diversity, $F$ - inbreeding index

\begin{tabular}{ccccccc}
\hline \hline Group & $\boldsymbol{N}$ & $\boldsymbol{A}_{\boldsymbol{N}}$ & $\boldsymbol{A}_{E}$ & $\boldsymbol{H}_{\boldsymbol{o}}$ & $\boldsymbol{H}_{\boldsymbol{e}}$ & $\boldsymbol{F}$ \\
\hline Roach & 63.000 & 18.800 & 9.252 & 0.749 & 0.858 & 0.123 \\
Bream & 50.000 & 11.200 & 5.582 & 0.592 & 0.731 & 0.247 \\
Hybrid & 39.000 & 18.600 & 9.369 & 0.759 & 0.884 & 0.147 \\
\hline \hline
\end{tabular}

In all analyzed groups, at least half of the loci significantly deviated from HWE. Also, Wright's F-statistics pointed to the increased inbreeding, with elevated values of $F_{I S}$ and $F_{I T}$ that varied across loci. Overall mean $F_{S T}$ was moderate and equalled 0.081 (Table 3). These findings were corroborated by AMOVA that revealed that most variation was within individuals (75\%), while variation between individuals and among groups was $14 \%$ and $11 \%$, respectively. Analysis of pairwise $F_{S T}\left(p F_{S T}\right)$ revealed clear genetic differentiation between bream and roach (0.110), low differentiation between roach and hybrids (0.027), as well as between bream and hybrids (0.050).

Table 3. Overall F-statistics for each analyzed locus

\begin{tabular}{ccccccc}
\hline \hline & Ca1 & CypG24 & Ca3 & Z21908 & CygG27 & Mean \\
\hline $\mathrm{F}_{\text {IS }}$ & 0.034 & 0.322 & 0.179 & 0.281 & -0.024 & 0.158 \\
$\mathrm{~F}_{\text {IT }}$ & 0.104 & 0.447 & 0.207 & 0.323 & 0.032 & 0.223 \\
$\mathrm{~F}_{\text {ST }}$ & 0.073 & 0.184 & 0.033 & 0.058 & 0.055 & 0.081 \\
\hline \hline
\end{tabular}

Table 1. Size ranges (in bp) for investigated microsatellite loci in bream, roach and hybrids. Numbers in brackets represent the observed number of private alleles

\begin{tabular}{llll}
\hline \hline Locus name & Abramis brama & Rutilus rutilus & Abramis $\times$ Rutilus \\
\hline Ca1 & $93-133$ & $99-129(4)$ & $91-133(1)$ \\
Ca3 & $231-305(2)$ & $235-333(10)$ & $231-341(4)$ \\
CypG24 & $186 / 190 / 196 / 201(1)$ & $176-234(3)$ & $186-222$ \\
CypG27 & $279-333(3)$ & $237-287(7)$ & $241-331(5)$ \\
Z21908 & $141-159$ & $139-177(4)$ & $139-169$ \\
CypG30 & $173-231$ & - & $173-231$ \\
Rru2 & 92 & $88-104$ & $84-104$ \\
\hline \hline
\end{tabular}


Table 4. Putative hybrid specimens as diagnosed using morphology, ITS1, cytb and microsatellite genotypic class assignments using STRUCTURE and NewHybrids. A - Abramis brama, $\mathrm{R}-$ Rutilus rutilus, $\mathrm{H}-$ hybrid, $\mathrm{P} 1-1^{\text {st }}$ parental species, $\mathrm{P} 2-2^{\text {nd }}$ parental species, F1 $-F_{1}$ generation, $F 2-F_{2}$ generation, $B 1-$ backcrossed with $1^{\text {st }}$ parental species, B2 - backcrossed with $2^{\text {nd }}$ parental species

\begin{tabular}{|c|c|c|c|c|c|c|c|c|c|c|c|}
\hline \multirow{2}{*}{ Sample } & \multirow{2}{*}{ Morphology } & \multirow{2}{*}{ ITS1 } & \multirow{2}{*}{ cytb } & \multicolumn{2}{|c|}{ STRUCTURE $q$ I values } & \multicolumn{6}{|c|}{ NewHybrids ql values } \\
\hline & & & & $\mathbf{R}$ & A & P1 & $\mathbf{P 2}$ & F1 & F2 & B1 & B2 \\
\hline H59 & $\mathrm{H}$ & $\mathrm{H}$ & $\mathrm{R}$ & 0.177 & 0.823 & 0.859 & 0.011 & 0 & 0.120 & 0.009 & 0.002 \\
\hline H88 & $\mathrm{H}$ & $\mathrm{H}$ & A & 0.247 & 0.753 & 0.020 & 0.009 & 0.007 & 0.893 & 0.014 & 0.058 \\
\hline H89 & $\mathrm{H}$ & $\mathrm{H}$ & A & 0.837 & 0.163 & 0.953 & 0 & 0 & 0.038 & 0.009 & 0 \\
\hline H91 & $\mathrm{H}$ & $\mathrm{H}$ & A & 0.576 & 0.424 & 0.393 & 0.024 & 0.002 & 0.537 & 0.024 & 0.020 \\
\hline H119 & $\mathrm{H}$ & $\mathrm{H}$ & A & 0.364 & 0.636 & 0.704 & 0.002 & 0.003 & 0.255 & 0.030 & 0.006 \\
\hline H139 & $\mathrm{H}$ & $\mathrm{H}$ & A & 0.412 & 0.588 & 0.901 & 0 & 0 & 0.090 & 0.009 & 0.001 \\
\hline H140 & $\mathrm{H}$ & $\mathrm{H}$ & A & 0.552 & 0.448 & 0.025 & 0.046 & 0.006 & 0.851 & 0.009 & 0.062 \\
\hline H141 & $\mathrm{H}$ & $\mathrm{H}$ & A & 0.365 & 0.635 & 0.160 & 0.003 & 0.001 & 0.786 & 0.019 & 0.030 \\
\hline H143 & $\mathrm{H}$ & $\mathrm{H}$ & A & 0.264 & 0.736 & 0.881 & 0.000 & 0.001 & 0.099 & 0.018 & 0.001 \\
\hline H144 & $\mathrm{H}$ & $\mathrm{H}$ & A & 0.471 & 0.529 & 0.403 & 0.036 & 0.003 & 0.521 & 0.015 & 0.023 \\
\hline H145 & $\mathrm{H}$ & $\mathrm{H}$ & A & 0.081 & 0.919 & 0.933 & 0 & 0 & 0.056 & 0.010 & 0 \\
\hline H146 & $\mathrm{H}$ & $\mathrm{H}$ & $\mathrm{R}$ & 0.706 & 0.294 & 0.033 & 0.026 & 0.002 & 0.905 & 0.013 & 0.021 \\
\hline H147 & $\mathrm{H}$ & $\mathrm{H}$ & A & 0.362 & 0.638 & 0.024 & 0.010 & 0.001 & 0.943 & 0.011 & 0.011 \\
\hline H149 & $\mathrm{H}$ & $\mathrm{H}$ & A & 0.199 & 0.801 & 0 & 0.006 & 0.006 & 0.912 & 0.007 & 0.069 \\
\hline H151 & $\mathrm{H}$ & $\mathrm{H}$ & $A$ & 0.361 & 0.639 & 0.871 & 0 & 0.001 & 0.114 & 0.013 & 0.001 \\
\hline H152 & $\mathrm{H}$ & $\mathrm{H}$ & A & 0.396 & 0.604 & 0.721 & 0.001 & 0 & 0.248 & 0.027 & 0.002 \\
\hline H156 & $\mathrm{H}$ & $\mathrm{H}$ & $A$ & 0.560 & 0.440 & 0.030 & 0.052 & 0.001 & 0.842 & 0.001 & 0.074 \\
\hline H157 & $\mathrm{H}$ & $\mathrm{H}$ & $A$ & 0.253 & 0.747 & 0.212 & 0.011 & 0.003 & 0.701 & 0.066 & 0.007 \\
\hline H158 & $\mathrm{H}$ & $\mathrm{H}$ & A & 0.288 & 0.712 & 0.138 & 0 & 0.029 & 0.760 & 0.055 & 0.018 \\
\hline H159 & $\mathrm{H}$ & $\mathrm{H}$ & $A$ & 0.565 & 0.435 & 0.014 & 0.022 & 0.001 & 0.935 & 0.003 & 0.026 \\
\hline H160 & $\mathrm{H}$ & $\mathrm{H}$ & $A$ & 0.436 & 0.564 & 0.429 & 0 & 0 & 0.555 & 0.010 & 0.006 \\
\hline H162 & $\mathrm{H}$ & $\mathrm{H}$ & $A$ & 0.516 & 0.484 & 0.897 & 0 & 0 & 0.091 & 0.008 & 0.004 \\
\hline H163 & $\mathrm{H}$ & $\mathrm{H}$ & $A$ & 0.686 & 0.314 & 0.556 & 0 & 0 & 0.432 & 0.009 & 0.003 \\
\hline H167 & $\mathrm{H}$ & $\mathrm{H}$ & A & 0.563 & 0.437 & 0.327 & 0.017 & 0.001 & 0.580 & 0.072 & 0.003 \\
\hline H168 & $\mathrm{H}$ & $\mathrm{H}$ & A & 0.479 & 0.521 & 0.036 & 0.002 & 0.004 & 0.919 & 0.010 & 0.029 \\
\hline H170 & $\mathrm{H}$ & $\mathrm{H}$ & $A$ & 0.498 & 0.502 & 0.053 & 0.164 & 0 & 0.692 & 0.003 & 0.089 \\
\hline H171 & $\mathrm{H}$ & $\mathrm{H}$ & $A$ & 0.294 & 0.706 & 0.439 & 0.010 & 0 & 0.540 & 0.007 & 0.003 \\
\hline H172 & $\mathrm{H}$ & $\mathrm{H}$ & A & 0.293 & 0.707 & 0.533 & 0.003 & 0 & 0.418 & 0.005 & 0.041 \\
\hline H173 & $\mathrm{H}$ & $\mathrm{H}$ & A & 0.340 & 0.660 & 0.035 & 0.004 & 0.004 & 0.870 & 0.002 & 0.085 \\
\hline H174 & $\mathrm{H}$ & $\mathrm{H}$ & $A$ & 0.062 & 0.938 & 0 & 0.041 & 0.001 & 0.882 & 0.001 & 0.074 \\
\hline H175 & $\mathrm{H}$ & $\mathrm{H}$ & $A$ & 0.265 & 0.735 & 0.001 & 0.040 & 0.001 & 0.885 & 0.002 & 0.071 \\
\hline H177 & $\mathrm{H}$ & $\mathrm{H}$ & $A$ & 0.460 & 0.540 & 0.403 & 0.030 & 0.002 & 0.523 & 0.024 & 0.017 \\
\hline H178 & $\mathrm{H}$ & $\mathrm{H}$ & $A$ & 0.333 & 0.667 & 0.875 & 0.015 & 0 & 0.104 & 0.006 & 0.001 \\
\hline H179 & $\mathrm{H}$ & $\mathrm{H}$ & $\mathrm{R}$ & 0.528 & 0.472 & 0.607 & 0.001 & 0 & 0.380 & 0.005 & 0.006 \\
\hline B125 & $\mathrm{R}$ & $\mathrm{H}$ & $\mathrm{R}$ & 0.425 & 0.575 & 0.031 & 0.039 & 0 & 0.881 & 0.002 & 0.047 \\
\hline D75 & A & $\mathrm{H}$ & $A$ & 0.891 & 0.109 & 0.613 & 0.012 & 0 & 0.345 & 0.028 & 0.002 \\
\hline D79 & A & $\mathrm{H}$ & $A$ & 0.843 & 0.157 & 0.921 & 0 & 0 & 0.065 & 0.011 & 0.002 \\
\hline D82 & $A$ & $\mathrm{H}$ & A & 0.760 & 0.240 & 0.888 & 0 & 0 & 0.105 & 0.006 & 0 \\
\hline D87 & A & $\mathrm{H}$ & A & 0.961 & 0.039 & 0.872 & 0.007 & 0 & 0.105 & 0.014 & 0.001 \\
\hline
\end{tabular}


The assignment test (Paetkau et al., 1995; Paetkau et al., 2004) showed clear differentiation between bream and roach, but also the genetic similarity between parental species and the hybrid group. When all three groups were compared, the hybrid group was positioned between bream and roach, with apparent dispersion and admixture of hybrid individuals with the other two clusters. These were confirmed by the results of PCoA analysis (Fig. 2). STRUCTURE analysis based on the MCMC method also supported such relations (Fig. 3). Assuming K=2, STRUCTURE revealed that $97.5 \%$ of bream individuals

Principal Coordinates (PCOA)

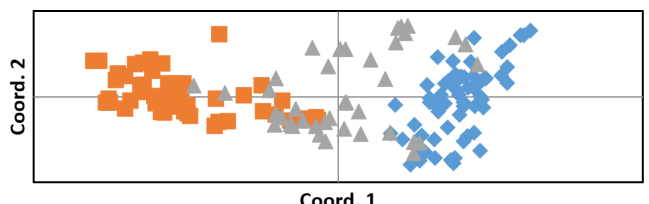

Roach

Bream

$\triangle$ Hybrid

Coord. 1

Fig 2. Results of the Principal Coordinates Analysis (PCOA)

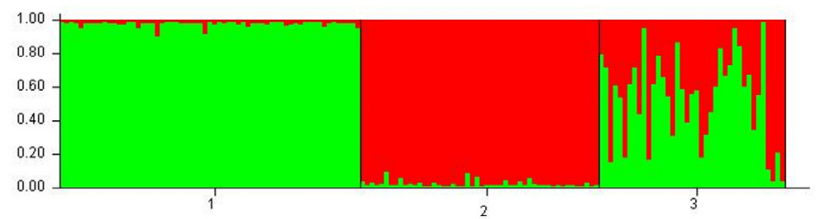

Fig 3. Results of STRUCTURE analysis based on MCMC method (cluster I - bream, green; cluster II - roach, red; Groups: 1 - bream, 2 - roach, 3 - hybrids). Each column represents one individual. belonged to cluster I (roach), while $97.8 \%$ of roach fell into cluster II. Most of the hybrids were distributed relatively equally between both clusters (Table 4).

Four individuals assigned as bream and one specimen assigned as roach according to morphology and microsatellite data displayed an ITS1 profile characteristic of hybrids (Table 4). Analysis of cytochrome $b$ showed that those four putative bream individuals were mothered by bream, while the roach had roach maternal origin. Nine samples, described as hybrids based on morphology and microsatellites, gave only one band for ITS1, specific for roach. Cytochrome $b$ showed that six of them had roach maternal origin, while three displayed a bream profile. Finally, ten samples were thought to be hybrids according to morphology and ITS1 profiles displayed bias towards parental clusters in STRUCTURE analysis $(71.2 \%$ - 93.8\%). Nine of them were assigned to the roach cluster, while one was placed in the bream group. The applied analysis showed concordance with the results of ITS1 profiling in most of the cases. Out of 40 samples that appeared to be hybrids when analyzed with ITS1 marker, $92.5 \%$ were confirmed by MCMC analysis as well.

Whether any of the analyzed specimens represented a post $-F_{1}$ individual was further tested by NewHybrids software. Based on the allele frequencies of multilocus genotypes, this software estimates the posterior probability $(q l)$ that a given individual falls in each of the set categories: parent species (i.e. P1 and P2), $F_{1}$, $F_{2}$ and backcrosses (i.e. B1 or B2). Of all samples that displayed the hybrid ITS1 profile, 56.4\% were classified as $F_{2}$ hybrids when the posterior probability threshold of

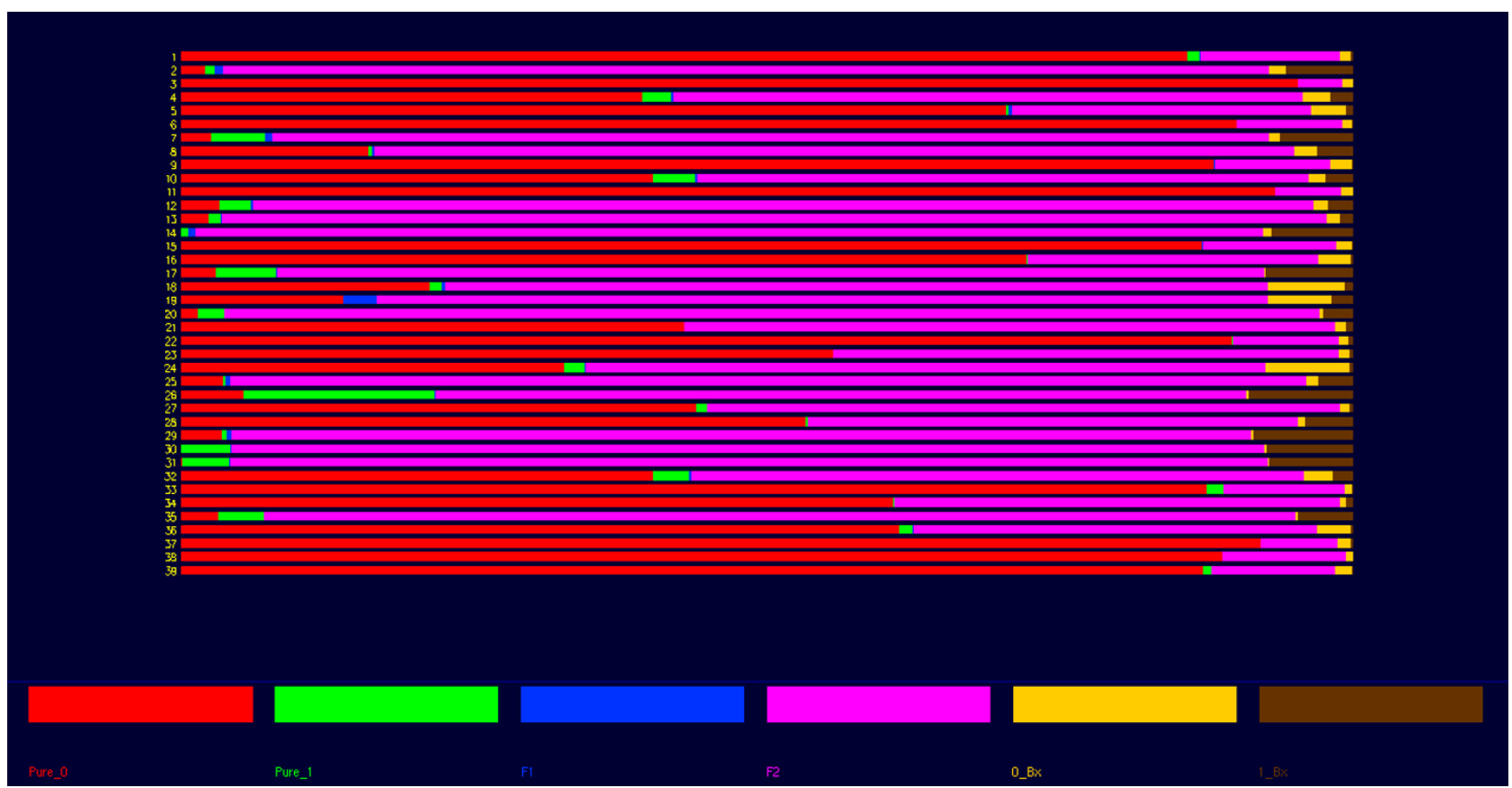

Fig 4. The classification of hybrid individuals based on the NewHybrids analysis to six set groups: Pure_0 $-1^{\text {st }}$ parent species (red), Pure_1 $-2^{\text {nd }}$ parent species (green), F1 $-F_{1}$ generation (blue), F2 $-F_{2}$ generation (purple), $0 \_B x-$ backcrossed with $1^{\text {st }}$ parental species (yellow), 1 B $B x$ - backcrossed with $2^{\text {nd }}$ parental species. Each line represents one individual (brown) 
0.5 was applied, while $43.6 \%$ were categorized as pure parental form. No $F_{1}$ or backcross categories were found (Fig. 4, Table 4). Loci Ca3, CypG27 and 221908 were most informative for determining the hybrid category.

\section{DISCUSSION}

Intergeneric hybridization in the Cyprinidae family has been known since as early as the late $19^{\text {th }}$ century (Kodukhova, 2010). The most common hybridizing pair within the cyprinids appears to be the roach $\times$ bream, especially in lakes and reservoirs (Kuparinen et al., 2014). Modrac Reservoir was established in 1964 by constructing a dam across the River Spreča to supply water for the surrounding industry. The reservoir flooded parts of riverbeds of the rivers Spreča and Turija, merging their fish communities in the new habitat and facilitating hybridization events. Notwithstanding more than 50 years of its existence, the data on the ichthyological structure of Modrac Reservoir have been very scarce (Habeković et al., 1981; Adrović et al., 2009a; Adrović et al., 2012). A study from the 1980s showed the prevalence of common bleak Alburnus alburnus (L. 1758) (64.34\% of the total catch; Habeković et al., 1981). However, some 30 years later, the dominance shifted to roach Rutilus rutilus and bream Abramis brama (31.25\% and 19.56\%, respectively; Adrović et al., 2009a). The first report of natural hybridization between these two species in Modrac Reservoir and in Bosnia and Herzegovina, in general, was given by Adrović et al. (2009a, b). Based on the analyses of several morphomeristic characteristics, most prominently the length of the anal fin base and the number of rays in the anal fin, the authors structured their catch as $24 \%$ bream, $16.4 \%$ roach and $21.6 \%$ hybrids. The present study offers the first insight into the genetic composition of the hybrid individuals and both parental species from this location, as well as the hybridization direction.

Our results confirmed unhindered natural hybridization between roach and bream in Modrac Reservoir, regardless of the marker system used. Since there was no significant difference between the results of morphological and molecular analysis, two biometric traits (i.e. base length and the number of rays in the anal fin) proposed by Adrović et al. (2009a) as the best discriminators for bream $x$ roach hybrids from Modrac Reservoir proved to be reliable (Fig. 1).

According to morphological observations, 44 individuals were characterized as hybrids, of which 35 specimens (79.5\%) displayed the hybrid profile when analyzed with ITS1 marker. Finally, 32 (72.7\%) were assigned as hybrids based on $0.1<q l<90 \%$ parameter (Vähä and Primmer, 2006) in STRUCTURE analysis. There was a concordance of $91.4 \%$ in the results of hybrid discrimination when only molecular markers (i.e. ITS1 and microsatellites) were concerned. Our results are in line with those reported by Konopiński and Amirowicz (2017) who investigated the genetic composition of bream $\times$ roach hybrids in Dobczyce
Reservoir in southern Poland, based on 16 microsatellites derived for the species Leuciscus leuciscus (Cyprinidae). Of seven microsatellite loci used in this study, Rru2 was monomorphic in bream while CypG30 did not amplify in roach, despite the previous reports of successful amplification in $R$. rutilus from the River Bourne, Surrey, UK (Hamilton and Tyler, 2008). Although it could be argued that the number of employed microsatellite markers was low, private alleles were observed for all five loci used in calculations (Table 1), proving their informativeness for the delineation of parental species and hybrid individuals. The mean gene diversity for hybrids was high (0.884) in our study, as it was in Konopiński and Amirowicz (2017), in which the mean genetic diversity in hybrids $(0.716)$ was slightly lower than in $R$. rutilus (0.731), but higher than in A. brama (0.370). For the chosen microsatellite set, hybrids from our survey displayed higher gene diversity than both parent species (Table 2).

Analysis of the mitochondrial cytb region revealed that hybrids in Modrac Reservoir originate predominantly from the mating between bream females and roach males. This is in agreement with previous studies (Wyatt et al., 2006; Hayden et al., 2010; Kuparinen et al., 2014; Konopiński and Amirowicz, 2017) and appears to be a universal direction of hybridization of these two species, across their overlapping range in Europe.

When all markers and analyses were concerned, 16 specimens appeared as undoubted hybrid individuals. However, similar to other studies (Aboim et al., 2010), the hybridization rate depended highly on the investigated marker system. This finding further justifies the recommendation of using different marker systems when conducting hybridization surveys (Scribner et al., 2001).

The most surprising results of our study were those obtained by NewHybrids software. Over $50 \%$ of the specimens with ITS1 hybrid profile were classified as $F_{2}$ hybrids when the threshold of 0.5 was applied (Table 4). This contradicts the most available reports on bream $\times$ roach hybridization in Europe that showed either the complete presence of $F_{1}$ individuals in the hybrid population (Kuparinen et al., 2014; Konopiński and Amirowicz, 2017) or their prevalence of over $90 \%$ (Toskano et al., 2010; Hayden et al., 2010). However, despite their abundance in most habitats where they occur, no incontestable evidence of hybrid swarming has been found so far. As shown by Tominaga et al. (2018), such distribution of hybrid classes in a population (no $F_{1^{\prime}}$ all $F_{2}$, no backcrosses) could be seen in those habitats where the pure parental species currently rarely come into direct contact around the hybrid zone and all gene flow is conducted via hybrid swarms. They further showed that NewHybrids assigned the majority (77.3\%) of simulated individuals from posterior hybrid generations (i.e. $F_{3^{\prime}} F_{4}$ and $F_{5}$ ) into $F_{2}$ class. Such findings were expected due to the limitation of the software (six a priori assumed classes) to predict post- $F_{2}$ classes individually. Therefore, when our results are considered, the possibility of having 
posterior hybrid generations in our sample as well cannot be disregarded, which would indicate the existence of the hybrid swarm in the investigated part of Modrac Reservoir. Some previous reports considered bream $\times$ roach hybrids to be fertile and able to produce offspring with either of parental species, both under experimental conditions (Pitts et al. 1997; Wood and Jordan, 1987) and in the wild (Toscano et al., 2010). Implications of post- $F_{1}$ hybridization and backcrossing, based only on discrepancies between morphological and molecular data, were given in some studies (Wyatt et al., 2006; Hayden et al., 2010; Toscano et al., 2010) but were disputed by some authors (Konopiński and Amirowicz, 2017) on the basis of the need for further confirmation using more complex marker systems and analyses. As far as it is known, our results are the first indication of $F_{2}$ bream $\times$ roach hybrid individuals in the natural habitat when following the approach suggested by Konopiński and Amirowicz (2017). However, to further confirm such findings, analysis of a larger sample and additional microsatellites would be beneficial. Although speculative, a possible explanation for the occurrence of the $F_{2}$ generation (and putative posterior hybrid generations) could be an ecological adaptation of hybrid individuals in Modrac Reservoir and a lack of selection pressure against their phenotype. It was reported that the intermediate morphology of $A$. brama $\times R$. rutilus hybrids does not pose any significant disadvantage compared to parental species (Toscano et al., 2010). Furthermore, these hybrids have been shown to be more flexible in food choice than the parental species (Hayden et al., 2011). This could make them more resistant to fluctuations in available food, allowing for faster growth and conquest of new niches in the habitat. Such resilience is particularly advantageous in habitats under extensive anthropogenic pressure such as Modrac Reservoir (water level fluctuations, pollution, overfishing, etc.). If that is the case, then the existence of the hybrid swarm cannot be excluded, justifying the result of NewHybrids analysis seen in this study.

The observed distribution of parental and hybrid genotypes $(43.6 \%$ and $56.4 \%$, respectively) indicates that the hybrid zone of Modrac Reservoir follows the intermediate or "flat" hybrid model (Jiggins and Mallet, 2000), at least in the case of investigated species. Although a study by Konopiński and Amirowicz (2017) on bream $\times$ roach hybridization in Dobczyce Reservoir showed a clear unimodal hybrid zone, the occurrence of transitional hybrid zones with "flat" genotype distribution is not unusual for cyprinid fish (Meagher and Dowling, 1991; Costedoat et al., 2005, McKenzie et al., 2016). In an exogenous, post-zygotic selection, parental genotypes are favored in their typical habitats, but hybrids display higher fitness in intermediate habitats. Whether this type of selection is the driving force in Modrac Reservoir is still to be confirmed with further experimental data.

Our data also indicated a possible introgressive hybridization between two parental species. Four specimens, that were assigned as bream according to morphological and mitochondrial screening, clearly grouped into roach clusters based on the STRUCTURE results $(q />0.9$ ) or displayed high $q /$ values (i.e. 0.891, 0.843 and 0.760). Although mostly evidenced by mitochondrial introgression, introgressive hybridization between distant species has been previously documented in cyprinids (Sousa-Santos et al., 2014; Almodóvar et al., 2012; Aboim et al., 2010). In our survey, findings indicated the unidirectional type of introgression, probably driven by backcrossing of hybrid individuals, with bream mtDNA, with roach males. However, bidirectionality cannot be excluded until a larger sample set of all three groups is investigated. Varying hybridization rates, seen in the hybrid group in this study (Table 4), speak in favor of lasting and dynamic interspecific relations in Modrac Reservoir fish community.

Our results confirmed the existence of bream $\times$ roach hybrids based on various markers, but reliable data on the hybrid abundance in the fish community of Modrac Reservoir are still lacking. To explain whether the survival and mating success of post- $F_{1}$ individuals is driven by the extended spawning season, the possible broader ecological valence of hybrids, abundance in habitat or the combination of various causes, further studies on their ecology are needed. It would be valuable to investigate if similar hybridization and introgression scenarios are present in other cyprinid species in Modrac Reservoir fish community. The hybridization between Abramis brama and Rutilus rutilus clearly represents a convenient model for studying adaptation and hybridization patterns in European cyprinids.

\section{ACKNOWLEDGEMENTS}

The authors would like to thank mr.sc. Muhedin Mašović and dr.sc. Isat Skenderović for their assistance in collecting samples at Modrac Reservoir. We kindly thank the reviewers for their comments and suggestions that improved the quality of the paper.

\section{MOLEKULARNA STRUKTURA I OBRASCI HIBRIDIZACIJE HIBRIDA Abramis brama $\times$ Rutilus rutilus IZ AKUMULACIJE MODRAC, BOSNA I HERCEGOVINA}

\section{SAŽETAK}

Interspecijska hibridizacija u obitelji Cyprinidae zabilježena je širom svijeta, a Abramis brama (deverika) i Rutilus rutilus (bodorka) su jedan od često prijavljenih hibridizirajućih parova. Jedini opis takvog događaja u Bosni i Hercegovini potječe iz akumulacije Modrac. Koristeći morfološke i molekularne markere, istražili smo prisutnost hibrida, odredili smjer hibridizacije i procijenili 
strukturu hibridnih skupina u ovom ekosustavu. Naša su otkrića potvrdila nesmetanu prirodnu hibridizaciju bodorke $\mathrm{i}$ deverike u akumulaciji Modrac. Primjenom NewHybrids softvera, preko $50 \%$ hibridnih primjeraka klasificirano je kao $F_{2}$ hibridi, dok su ostali kategorizirani kao čisti roditeljski oblik, što je prvi takav nalaz u Europi. Analiza mitohondrijskog citokroma $b$ pokazala je da $90 \%$ hibridnih jedinki ima majčinsko podrijetlo od deverike. Hibridna skupina pokazala je veće srednje vrijednosti promatrane heterozigotnosti i raznolikosti gena u odnosu na obje roditeljske vrste. Otkriveni su znakovi introgresivne hibridizacije između roditeljskih vrsta. Čini se da hibridna zona akumulacije Modrac slijedi intermedijarni ili "ravni" hibridni model zasnovan na uravnoteženoj raspodjeli roditeljskih i hibridnih genotipova. Potrebna su daljnja istraživanja kako bi se rasvijetlili čimbenici koji omogućuju preživljavanje $\mathrm{i}$ uspjeh $\mathrm{u}$ parenju jedinki poslije $\mathrm{F}_{1}$ generacije.

Ključne riječi: deverika, bodorka, NewHybrids, post- $\mathrm{F}_{1}$, introgresija

\section{REFERENCES}

Aboim, M. A., Mavárez, J., Bernatchez, L., Coelho, M. M. (2010): Introgressive hybridization between two Iberian endemic cyprinid fish: a comparison between two independent hybrid zones. Journal of Evolutionary Biology, 23, 4, 817-828.

Adrović, A., Skenderović, I., Salihović, J., Stjepić, Š. (2012): Biodiversity of Fish Fauna of the Gostelja River and Reservoire Modrac. In: International Conference "Structure and dynamics of ecosystems Dinarides - status, possibilities and prospects". 2011 June. Sarajevo. Sarajevo, Akademija nauka i umjetnosti Bosne i Hercegovine, p. 277-290

Adrović, A., Škrijelj, R., Skenderović, I. (2009a): The first record and morphological characteristics of hybrid of Rutilus rutilus $\mathrm{x}$ Abramis brama from Modrac reservoir, Bosnia and Herzegovina. Croatian Journal of Fisheries, 67, 1, 11-23.

Adrović, A., Škrijelj, R., Skenderović, I. (2009b): Ecologial Characteristics of the Roach (Rutilus rutilus L.) and Bream (Abramis brama L.) in the Reservoir of the Lake Modrac. Acta Agriculturae Serbica, 14, 27, 23-33.

Allendorf, F.W., Waples, R.S. (1996): Conservation and genetics of salmonid fishes. pp. 238-280. In: Avise, J.C., Hamrick, J.L. (eds.), Conservation Genetics: Case Histories from Nature. Chapman and Hall, New York, USA, 512 pp.

Almodóvar, A., Nicola, G. G., Leal, S., Torralva, M., Elvira, B. (2012): Natural hybridization with invasive bleak Alburnus alburnus threatens the survival of Iberian endemic calandino Squalius alburnoides complex and Southern Iberian chub Squalius pyrenaicus. Biological Invasions, 14, 2237-2242.

Anderson, E.C., Thompson, E.A. (2002): A model-based method for identifying species hybrids using multilocus genetic data. Genetics, 160, 3, 1217-29.

Baerwald, M. R., May, B. (2004): Characterization of microsatellite loci for five members of the minnow family Cyprinidae found in the Sacramento-San Joaquin Delta and its tributaries. Molecular Ecology Notes, 4, 3, 385-390.

Barinova, A., Yadrenkina, E., Nakajima, M., Taniguchi, N. (2004): Identification and characterization of microsatellite DNA markers developed in ide Leuciscus idus and Siberian roach Rutilus rutilus. Molecular Ecology Notes, 4, 1, 86-88.

Brody, J. R., Kern, S. E. (2005): Sodium boric acid: a Tris free, cooler conductive medium for DNA electrophoresis. Biotechniques, 38, 1, 60.

Campton, D.E. (1987): Natural hybridization and introgression in fishes: Methods of detection and genetic interpretations. pp. 161-192. In: Ryman, N., Utter, F. (eds.), Population Genetics and Fishery Management. University of Washington Press, Seattle, WA, USA, 420 pp.

Costedoat, C., Pech, N., Salducci, M-D., Chappaz, R., Gilles, A. (2005): Evolution of mosaic hybrid zone between invasive and endemic species of Cyprinidae through space and time. Biological Journal of the Linnean Society, 85, 135-155.

Cowx, I.G. (1983): The biology of bream Abramis brama (L) and its natural hybrid with roach, Rutilus rutilus (L), in the River Exe. Journal of Fish Biology, 22, 631-646.

Dent, A.E., von Holdt, B.M. (2012): STRUCTURE HARVESTER: a website and program for visualizing STRUCTURE output and implementing the Evanno method. Conservation Genetic Resources, 4, 359-361.

Dimsoski, P., Toth, G. P., Bagley, M. J. (2000): Microsatellite characterization in central stoneroller Campostoma anomalum (Pisces: Cyprinidae). Molecular Ecology, 9, 12, 2187-2189.

Dubut, V., Sinama, M., Martin, J-F., Meglécz, E., Fernandez, J., Chappaz, R., Gilles, A., Costedoat, C. (2010): Cross-species amplification of 41 microsatellites in European cyprinids: A tool for evolutionary, population genetics and hybridization studies. BMC Research Notes, 3, 135.

Durmić-Pašić, A., Pojskić, N., Kalamujić, B., Hadžiselimović, R. (2005): Genetic characterization of fish populations and its use in landscape conservation in Bosnia and Herzegovina. International workshop "The role of biotechnology for the characterization and conservation of crop, forestry, animal and fishery genetic resources". 2005, Mar 5-7, Turin, Italy. Book of proceedings, 173-174.

Excoffier, L., Smouse, P.E., Quattro, J.M. (1992): Analysis of molecular variance inferred from metric distances among DNA haplotypes: application to human mitochondrial DNA restriction data. Genetics, 131, 479-491.

Frankham, R., Ballou, J.D., Briscoe, D.A. (2002): Introduction to Conservation Genetics. Cambridge. Cambridge, University Press.

Habeković, D., Homen, Z., Popović, J. (1981): Ihtiofauna akumulacijskog jezera "Modrac". Croatian Journal of Fisheries, 36, 1, 4-7.

Hamilton, P.B., Tyler, C.R. (2008): Identification of microsatellite loci for parentage analysis in roach Rutilus rutilus and eight other cyprinid fish by cross-species amplification, and a novel test for detecting hybrids between roach and other cyprinids. Molecular Ecology Resources, 8, 462-465.

Hartl, D.L., Clark, A.G. (1997): Principles of population genetics. Sinauer associates, Sunderland, MA, $519 \mathrm{pp}$.

Hayden, B., Massa-Gallucci, A., Caffrey, J., Harrod, C., Mariani, S., O'Grady, M., Kelly-Quinn, M. (2011): Trophic dynamics within a hybrid zone - interactions between an abundant cyprinid hybrid and sympatric parental species. Freshwater Biology, $56,1723-1735$.

Hayden, B., Pulcini, D., Kelly-Quinn, M., O'Grady, M., Caffrey, J., McGrath, A., Mariani, S. (2010): Hybridization between two cyprinid fishes in a novel habitat: genetics, morphology and life-history traits. BMC Evolutionary Biology, 10, 169. 
Hedrick, P.W. (1999): Highly variable loci and their interpretation in evolution and conservation. Evolution, 53, 313-318.

Jiggins, C. D., Mallet, J. (2000): Bimodal hybrid zones and speciations. Trends in Ecology \& Evolution, 15, 6, 250-255.

Kodukhova, Yu.V. (2010): Yearly Variations of Impact of Natural Hybrids of Bream and Roach (Abramis brama (L.) $\times$ Rutilus rutilus (L.)) in Rybinsk Reservoir. Rossiiskii Zhurnal Biologicheskikh Invasii, 2, 106-113.

Konopiński, M.K., Amirowicz, A. (2017): Genetic composition of a population of natural common bream Abramis brama $\times$ roach Rutilus rutilus hybrids and their morphological characteristics in comparison with parent species. The Journal of Fish Biology, 92, 2, 365-385.

Kuparinen, A., Vinni, M., Teacher A.G.F., Kähkönen, K., Merilä, J. (2014): Mechanism of hybridization between bream Abramis brama and roach Rutilus rutilus in their native range. Journal of Fish Biology, 84, 237-242.

Leary, R.F., Allendorf, F.W., Sage, G.K. (1995): Hybridization and introgression between introduced and native fish. pp. 91101. In: Schramm, H.L. and Piper, R.G. (eds.), Uses and Effects of Cultured Fishes in Aquatic Ecosystems Bethesda. American Fisheries Society, Symposium 15, Bethesda, USA.

Lin, L.I-K. (1989): A concordance correlation coefficient to evaluate reproducibility. Biometrics, 45, 255-268.

Lin, L.I-K. (2000): A note on the concordance correlation coefficient. Biometrics, 56, 324-325.

Matondo, B.N., Ovidio, M., Poncin, P., Vandewalle, P., Philippart, J.C. (2008): Morphological recognition of artificial $F_{1}$ hybrids between three common European cyprinid species: Rutilus rutilus, Blicca bjoerkna and Abramis brama. Acta Zoologica Sinica, 54, 1.

McKenzie, J.L., Dhillon, R.S., Schulte, P.M. (2016): Steep, coincident, and concordant clines in mitochondrial and nuclear-encoded genes in a hybrid zone between subspecies of Atlantic killifish, Fundulus heteroclitus. Ecology \& Evolution, 6, 16, 5771-5787.

Meagher, S., Dowling, T.E. (1991): Hybridization between the Cyprinid Fishes Luxilus albeolus, L. cornutus, and L. cerasinus with Comments on the Proposed Hybrid Origin of $L$. albeolus. Copeia, 4, 979-991.

Meirmans, P. G., Hedrick, P. W. (2011): Assessing population structure: FST and related measures. Molecular Ecology Resources, 11, 1, 5-18.

Miller, S.A., Dykes, D.D., Polesky, H.F. (1988): A simple salting-out procedure for extracting DNA from human nucleated cells. Nucleic Acids Research, 16, 1215.

Nei, M. (1987): Molecular Evolutionary Genetics. New York, Columbia University Press, 514 pp.

Pacheco, N.M., Congdon, B.C., Friesen, V.L. (2002): The utility of nuclear introns for investigating hybridization and genetic introgression: a case study involving Brachyramphus murrelets. Conservation Genetics, 3, 182-202.

Paetkau, D., Calvert, W., Stirling, I., Strobeck, C. (1995): Microsatellite analysis of population structure in Canadian polar bears. Molecular Ecology, 4, 3, 347-354.

Paetkau, D., Slade, R., Burden, M., Estoup, A. (2004): Genetic assignment methods for the direct, real-time estimation of migration rate: a simulation-based exploration of accuracy and power. Molecular Ecology, 13, 1, 55-65.

Peakall, R., Smouse, P.E. (2012): GenAIEx V5: Genetic Analysis in Excel. Populations Genetic Software for Teaching and Research. Bioinformatics, 28, 19, 2537-2539.

Perea, S., Böhme, M., Zupančič, P., Freyhof, J., Šanda, R., Özuluğ,
M., Abdoli, A., Doadrio, I. (2010): Phylogenetic relationships and biogeographical patterns in Circum-Mediterranean subfamily Leuciscinae (Teleostei, Cyprinidae) inferred from both mitochondrial and nuclear data. BMC Evolutionary Biology, 10, 1, 265.

Piry, S., Alapetite, A., Cornuet, J-M., Paetkau, D., Baudouin, L., Estoup, A. (2004): GeneClass2: A software for genetic assignment and first-generation migrant detection. Journal of Heredity, 95, 536-539.

Pitts, C.S., Jordan, D.R., Cowx, I.G., Jones, N.V. (1997): Controlled breeding studies to verify the identity of roach and common bream hybrids from a natural population. Journal of Fish Biology, 51, 686-696.

Pojskić N, Kalamujić B. (2015): Simulations based on moleculargenetic data in detection of expansion Salmo trutta allochtonous population in the Neretva River's tributaries. In: Proceedings of the $27^{\text {th }}$ International Congress for Conservation Biology and $4^{\text {th }}$ European Congress for Conservation Biology. Montpellier. Montpelier, ICCB/ECCB p. 539-540.

Pojskić, N. (2019): ALRATIO - R script for the analysis of relation between the effective and detected number of alleles. Genetics \& Applications, 3, 1, 77-80.

Pritchard, J. K., Stephens, M., Donnelly, P. (2000): Inference of population structure using multilocus genotype data. Genetics, 155, 2, 945-959.

Scribner, K.T., Page, K.S., Bartron, M.L. (2001): Hybridization in freshwater fishes: a review of case studies and cytonuclear methods of biological inference. Reviews in Fish Biology and Fisheries, 10, 293-323.

Sofradžija, A. (2009): Slatkovodne ribe Bosne i Hercegovine. Vijeće Kongresa bošnjačkih intelektualaca, Sarajevo, 110, 194 pp.

Sousa-Santos, C., Gante, H.F., Robalo, J., Proença Cunha, P., Martins, A., Arruda, M., Alves, M. J., Almada, V. (2014): Evolutionary history and population genetics of a cyprinid fish (Iberochondrostoma olisiponensis) endangered by introgression from a more abundant relative. Conservation Genetics, 15, 665-677.

Tominaga, A., Matsui, M., Yoshikawa, N., Eto, K., Nishikawa, K. (2018): Genomic displacement and shift of the hybrid zone in the Japanese Fire-Bellied Newt. Journal of Heredity, 109, 232-242.

Toscano, B.J., Pulcini, D., Hayden, B., Russo, T., Kelly-Quinn, M., Mariani, S. (2010): An ecomorphological framework for the coexistence of two cyprinid fish and their hybrids in a novel environment. Biological Journal of the Linnean Society, 99, 768-783.

Vähä, J.P., Primmer, C.R. (2006): Efficiency of model-based Bayesian methods for detecting hybrid individuals under different hybridisation scenarios and with different numbers of loci. Molecular Ecology, 15, 63-72.

Vuković T., Ivanović, B. (1971): Slatkovodne ribe Jugoslavije. Zemaljski muzej Bosne i Hercegovine, Sarajevo.

Wood, B., Jordan, D. R. (1987): Fertility of roach x bream hybrids, Rutilus rutilus (L.) x Abramis brama (L.), and their identification. The Journal of Fish Biology, 30, 249-261.

Wyatt, P.M.W., Pitts, C.S., Butlin, R. K. (2006): A molecular approach to detect hybridization between bream Abramis brama, roach Rutlius rutilus and rudd Scardinius erythrophthalmus. Journal of Fish Biology, 69, 52-71. 